\title{
Elaboration, shelf-life and quality evaluation of dishes prepared with pumpkin'
}

\author{
Isabel Beauchamp de Caloni and Evangelina Recio de Hernandez
}

\begin{abstract}
Pumpkin (Curcubita pepo L) variety Borinquen was prepared, evaluated and stored to determine shelf life of several dishes. Pumpkin custard and cake were found highly acceptable by a tasting panel. Pumpkin-with-cheese pies and a mixture of cooked mashed pumpkin with other ingredients suitable for fritters were highly acceptable both after 6 and 10 months storage when quick frozen in a plate freezer at $-40^{\circ} \mathrm{C}$ $\left(-40^{\circ} \mathrm{F}\right)$ and stored at $-23.3^{\circ} \mathrm{C}\left(-10^{\circ} \mathrm{F}\right)$.
\end{abstract}

\section{INTRODUCTION}

The demand for fresh and processed vegetables has been increasing in Puerto Rico. At present pumpkin is one of the most important of our agricultural products grown commercially in the south coast of the Island (11). Our pumpkin is native of tropical America, probably brought from Central America and Mexico to the Antilles by the Indians. It is believed that the indians cultivated the erop long before Columbus discovered America. For them it was their third most important crop preceded only by corn and beans (4).

There are many varieties of pumpkin that differ in size, shape, color and quality. The West Indian pumpkin, Curcubita pepo L., weighs an average of $5-6$ pounds, but some weigh as much as 10 pounds (14). Several superior varieties have been selected in Puerto Rico. The Agricultural Experiment Station of the University of Puerto Rico has developed the varieties Fortuna, Camagüey and Borinquen (4). They are middle sized ( $5-6$ pounds) and of various colors (deep green to white and green). Fortuna and Borinquen are more productive and of superior quality than unselected cultivars.

Pumpkins can be grown throughout the year, but best production is obtained when planted in early spring (6). In $1985-86$, the production of pumpkin in Puerto Rico was 420,000 ewt., with a farm value of $\$ 6.98$ million. Total production that year for all vegetables (peppers, cabbage, cucumber, tomato, pigeon peas and others) had a farm value of $\$ 21.254$ million (11).

${ }^{1}$ Manuseript submitted to Editorial Board November 24, 1986.

¿ Food Researcher and Assistant Food Technologist, Food Technology Laboratory, Agricultural Experiment Station, Mayagüez Campus, University of Puerto Rico, Río Piedras, Puerto Rico. 
Llorens et aI. (8) studied the production of pumpkin Borinquen selection of two farmers in the south coast of Puerto Rico. They obtained a yield of 133 and $149 \mathrm{cwt} / \mathrm{ha}$ with a farm value of $\$ 1,412.74$ and $\$ 1,698.14$, respectively. The total commercial yield of the crop was $12 \mathrm{t} / \mathrm{ha}$ (3).

Pumpkin as all other deep yellow vegetables is an excellent source of vitamin A. Half a cup $(125 \mathrm{~g})$ of the vegetable provides 7,840 International Units of the vitamin (1). Deficiency of this vitamin remains one of the most widespread forms of human malnutrition with its consequences of social and individual problems (9). The daily consumption of adequate quantities of fresh vegetables, mainly deep green or yellow, is always emphasized because of high vitamins and fiber content and few calories (2).

Latest studies on food consumption and nutrition in Puerto Rico indicate that our diet does not meet the recommended daily allowances for vitamin $A$, calcium and iron $(3,5,9)$.

If properly stored whole after harvesting, pumpkin can last from 1 to 3 months (6) but precooked dishes are important to promote more pumpkin consumption.

The present study was undertaken to determine the feasibility of developing, storing and evaluating pre-cooked dishes.

\section{MATERIALS AND METHODS}

Pumpkin of the Borinquen selection from Santa Isabel, Puerto Rico, was used to prepare several dishes. The fruits were washed, cleaned, hand peeled and trimmed. An average yield of $64.7 \%$ was obtained. Samples of cooked pumpkin boiled in salt water were submitted for sensory evaluation by a 12 to 16 member trained panel to determine the overall quality of the pumpkin before processing in standardized dishes.

The cooked pumpkin pulp was then tested in 4 recipes representing some potential uses at household level. Table 1 gives recipes for custard, cake, pie and fritters.

For custard, the mashed pulp was blended and mixed well with eggs, sugar, butter, milk, flour and cinnamon. The batter was poured into a prepared caramelized baking pan, placed over a double boiler (bain marie) and baked in preheated oven at $190.5^{\circ} \mathrm{C}\left(375^{\circ} \mathrm{F}\right)$ for 45 to 50 minutes or until a toothpick inserted in center of the custard came out clean. The custard was refrigerated before unmolding.

Pumpkin cake was prepared by mixing the dry ingredients in a bowl and adding oil. Pumpkin pulp, milk, eggs and spices were added to the mixture. The batter was ladled into a greased cake pan and baked in preheated oven at $176.6^{\circ} \mathrm{C}\left(350^{\circ} \mathrm{F}\right)$ for $50-55$ minutes or until a knife inserted in the center of the cake came out clean. The cake was cooled for 10 minutes before unmolding. 
TABLE 1.-Ingredients in 4 dishes made from Borinquen mumpkin selection

\begin{tabular}{lccccc}
\hline \multirow{2}{*}{ Ingredient } & \multicolumn{5}{c}{ Dish } \\
\cline { 2 - 6 } \multicolumn{1}{c}{ Custard } & Cake & Pie & Crust & Fritters \\
\hline Sugar & $900^{1}$ & 681 & $1590^{2}$ & - & 6810 \\
Milk & 113 & 257 & 675 & - & 908 \\
Wheat flour & 81 & - & $654^{3}$ & 180 & - \\
Butter or margarine & 46 & - & - & 630 & 454 \\
Eggs & 56 & 336 & - & - & 114 \\
Vanilla flavoring & 3 & 3 & - & - & 12 \\
Ground cinnamon & - & 12 & 10 & - & - \\
Cake flour & 1 & 3 & - & - & 18 \\
Cornstarch & - & 525 & - & - & - \\
Cream cheese & - & - & 28 & - & - \\
Lemon rind, grated & - & - & 795 & - & - \\
Salt & - & - & 10 & - & - \\
Vegetable shortening & - & - & - & 12 & - \\
\hline
\end{tabular}

${ }^{1}$ All amounts are measured in grams, except eggs.

2 For 3 round pans $12^{s}$ diameter each.

${ }^{3}$ Cream milk.

We made pies by beating mashed pumpkin pulp with cream cheese and sugar, adding the mixture of milk, cornstarch and flavoring with grated lemon peel and vanilla. We poured the batter into prepared uncooked pastry shells and put thin strips of pastry across the top of the filling. Pastry shell for pies was prepared by the Valldejuly (13) method: sift the flour and salt; cut in cold shortening with 2 knives; add cold milk slowly and mix until the mixture holds together in a ball; roll out with rolling pin and shape to cover the bottom and sides of a pie pan. Prepared pies were quick frozen in a plate freezer at $40^{\circ} \mathrm{C}\left(-40^{\circ} \mathrm{F}\right)$ and stored at $-23.3^{\circ} \mathrm{C}\left(-10^{\circ} \mathrm{F}\right)$ for monthly organoleptic evaluation. Frozen pies were baked in a preheated oven at $190^{\circ} \mathrm{C}\left(375^{\circ} \mathrm{F}\right)$ for 45 minutes and evaluated with a 6-point hedonic scale (12) by trained tasters up to 6-month storage.

For fritters, all ingredients were blended into a thick batter, placed in plastic containers, covered with a tight lid, quick frozen in a plate freezer at $-40^{\circ} \mathrm{C}\left(-40^{\circ} \mathrm{F}\right)$ and stored at $-23.3^{\circ} \mathrm{C}\left(-10^{\circ} \mathrm{F}\right)$ for monthly evaluation. Spoonfuls of the batter (previously defrosted at room temperature) were fried in cooking oil at $160^{\circ} \mathrm{C}\left(320^{\circ} \mathrm{F}\right)$, cooked until firm and crispy. The fritters of up to 10 -month storage were drained on absorbent paper towel and submitted for evaluation by tasters with a $+2,-2$ scale (7).

\section{RESULTS AND DISCUSSION}

Pumpkin of the Borinquen selection was found acceptable (from very acceptable to moderately acceptable) by the tasting panel in all attributes 
evaluated (5.60 to 4.10 out of 6.0 ), an indication that Borinquen is a good cultivar in terms of sensory appraisal.

Mean values for sensory evaluation of Borinquen selection were as follows: appearance, 5.60; flavor, 5.00; texture, 4.10; overall acceptability, $4.60 .^{3}$

Tables 1 and 2 present the acceptability of dishes prepared with Borinquen pumpkin. Table 2 shows the result of the overall evaluation (average of all tests carried out) of pumpkin custard and pumpkin cake by a 12 to 16 -member taste panel with the $+2,-2$ scale for general acceptability. Both dishes were highly accepted by the panelists, with mean scores of 1.57 and 1.67 out of 2.0 , respectively. The overall quality appraisal of custard and cake were: custard, 1.57; cake, 1.67. Both scores were highly acceptable. ${ }^{4}$

The following tabulation shows the monthly mean values of pumpkin fritters for overall acceptability. No significant difference was observed in 10-month storage of the frozen mixture when fried, confirmation of an acceptable pumpkin mixture for quality fritters.

$\begin{array}{cc}\text { Days in storage } & \text { Mean values }^{4} \\ 0 & 1.50 \\ 30 & 1.82 \\ 60 & 1.73 \\ 90 & 1.46 \\ 120 & - \\ 150 & - \\ 180 & 1.88 \\ 210 & 1.58 \\ 240 & 1.42 \\ 270 & - \\ 310 & 1.69\end{array}$

Table 4 shows the results of sensory appraisal of pumpkin-with-cream cheese pies, fresh and after frozen storage. The tasters, judging the pies of up to 6-month storage for appearance, flavor, mouthfeel (texture) and overall acceptability found them highly acceptable in all attributes evaluated.

The data completed indicates that acceptable dishes of pumplin can be prepared and stored frozen until needed. These dishes could add variety to meals and encourage the consumption of the crop as an important source of the much needed vitamin A. Minimum losses of the vitamin

${ }^{3} 6$ point hedonic scale $(6=$ like very much; $5=$ like; $4=$ like moderately; $3=$ neither like nor dislike; 2 = dislike a bit; 1 = dislike).

$+2,-2$ scale. $+2=$ very acceptable; $+1=$ acceptable; $0=$ questionable; $-1=$ slightly acceptable; $-2=$ not acceptable. 
TABLE 2.-Results of sensory evaluation of pumpkin with cream cheese pies when fresh and after 6-month storage

\begin{tabular}{ccccc}
\hline & \multicolumn{4}{c}{ Mean values $^{\mathrm{I}}$} \\
\cline { 2 - 5 } Days in storage & Appearance & Flavor & Texture & $\begin{array}{c}\text { Overall } \\
\text { acceptability }\end{array}$ \\
\hline 0 & 5.27 & 5.36 & 5.18 & 5.36 \\
30 & 5.42 & 5.50 & 5.33 & 5.50 \\
60 & 5.33 & 5.44 & 5.22 & 5.33 \\
90 & 5.44 & 5.69 & 5.69 & 5.63 \\
120 & - & - & - & - \\
150 & - & - & - & - \\
180 & 5.50 & 6.00 & 5.00 & 5.25 \\
\hline
\end{tabular}

6-point, hedomic scale, where $6=$ like very much; $5=$ like; $4=$ like moderately; $3=$ neither like or dislike; $2=$ dislike a bit; $1=$ dislike.

occur during frozen storage, whereas $60 \%$ or more of the vitamin is retained in the cooked dish (10).

\section{RESUMEN}

Elaboración, durabilidad y calidad de platos de calabaza

Se realizó un estudio de viabilidad para preparar, evaluar y determinar cómo el tiempo en almacén afecta la calidad de productos de calabaza de la variedad Borinquen (Curcubita pepo L.) cultivada en Santa Isabel, Puerto Rico.

Se prepararon bizcochos y flanes, pasteles dulces de calabaza y queso ("pies") y una mezcla apropiada para frituras de calabaza (tortitas de calabaza). Los pasteles y la mezcla para frituras se congelaron rápidamente en un congelador de placas a $-40^{\circ} \mathrm{C}\left(-40^{\circ} \mathrm{F}\right)$ y se mantuvieron a $-23.3^{\circ}$ C $\left(-10^{\circ} \mathrm{F}\right)$ para evaluación organoléptica mensual. Los datos recopilados mostraron buena aceptabilidad del bizcocho y el flan. El pastel de calabaza y queso resultó altamente aceptable para los catadores durante 6 meses de almacenamiento. Igualmente, las frituras de calabaza mantuvieron su alta calidad durante 10 meses.

\section{LITERATURE CITED}

1. Agricultural Research Service U.S. Department of Agriculture, 1975, Nutritive Value of American Foods in Common Units. Agric, Handb. 456, Washington, D.C.

2. Colón de Reguero, L. and S. Santiago, 1981. Tabla de Composición de Alimentos de Uso Corriente en Puerto Rico. Editorial Universitaria, Univ. P. R.

3. Comité Interagencial Guía de Alimentos de Puerto Rico, 1984. Informe sobre encuestas de consumo de alimentos en Puerto Rico, 1977-78.

4. Departamento de Agricultura, 1964. Revista de Agricultura de Puerto Rico, Vol. 51 Núm. 2, Julio-Diciembre.

5. Departamento de Salud, 1975-76. Estudios del Estado Nutricional de la Población de Puerto Rico. Resumen de datos más signifieativos.

6. Estación Experimental Agrícola, 1979. Conjunto Tecnológico para la Producción de Hortalizas. Publ. 102, 2da, ed, Marzo. 


\section{BEAUCHAMP DE CALONI \& RECIO DE HERNÁNDEZ/PUMPKIN}

7. Larmond, E., 1977. Laboratory Methods for the Sensory Evaluation of Food. Can. Dep. Agric., Res. Braneh Publ. 1637.

8. Llorens, A., E. González-Villafañe y D. Vargas, 1984. Gastos e Ingresos en la Produccion de Hortalizas en la Costa Sur de Puerto Rieo, Bol. 274 Esta. Exp. Agric. Univ. P. R.

9. National Research Council. Food and Nutrition Board, 1980. Recommended Dietary Allowances 9th ed, National Academy of Sciences, Washington, D.C.

10. National Academy of Sciences, 1975. Technology of the Fortification of Foods. Proceedings of a Workshop.

11. Oficina Estadisticas Agrícolas Departamento de Agricultura de Puerto Rico, 1985-86. Ingreso Bruto Agrícola de Puerto Rico, cifras preliminares 1985-86.

12. Pergaam, D. R. and F. J. Pilgrim, 1957. Hedonic scale methods for measuring food preferences. Food Technol, 11 (9) Insert 9.

18. Valldejuly-Aboy, C., 1962. Cocina Criolla, 6th ed, The Alpine Press, Inc., Boston, Mass.

14. Winters, H. F. and G. W. Miskimen, 1967. Vegetable Gardening in the Caribbean Area, Agric. Handb. No. 323. 